\title{
Simulation of PEM fuel cell integrated DVR using SRF-ANFIS controller for power quality enhancement
}

\author{
Bhavani $\mathbf{R}^{* * * *}$, Rathina Praba $\mathrm{N}^{*}$ and Ananthakumaran $\mathrm{S} * *$ \\ Department of Electrical and Electronics Engineering, Mepco Schlenk Engineering College, Sivakasi, Tamil Nadu, India \\ ** Department of Computer Science and Engineering, Koneru Lakshmaiah Education Foundation, Andhra Pradesh, India \\ *** Corresponding Author : bavanir@mepcoeng.ac.in
}

$\begin{array}{ll}\text { Submitted } & : 17 / 07 / 2019 \\ \text { Revised } & : 19 / 10 / 2020 \\ \text { Accepted } & : 28 / 10 / 2020\end{array}$

\begin{abstract}
Voltage related Power Quality (PQ) problems are attracting the eyes of researchers, as these cause huge loss in productivity and profitability for both utilities and consumers. Dynamic Voltage Restorer (DVR) is a well-known custom power device that provides an economical solution for the alleviation of power quality problems. Generally, battery energy storage is used as an input for DVR, but batteries are still bulky and costly and must be disposed once their chemicals are used, which limits the compensation capability of DVR. Nowadays, Fuel Cell (FC) technologies have attracted much attention owing to their high efficiencies and low emissions. This project aims to model and simulate Proton Exchange Membrane Fuel Cell (PEMFC) and is used as a DC input source for DVR. The suitable boost converter is designed and modelled to lift up the fuel cell output voltage suitable as DC link voltage for DVR. Adaptive Neuro Fuzzy Inference System (ANFIS) controller uses Synchronous Reference Frame Theory (SRF) algorithm to generate $\mathrm{d}$ and $\mathrm{q}$ axis components of reference signal for Voltage Source Converter (VSC) of DVR. This PEMFC DVR is verified for balanced and unbalanced voltage sag, swell, and harmonics using MATLAB/SIMULINK. A simulation result proves that this PEMFC DVR is capable of providing a technically advanced and economic solution for balanced and unbalanced voltage sag and swell. During compensation, the DVR DC input voltage is also preserved as constant, which enhances the compensation capability of DVR.
\end{abstract}

Keywords: Power quality (PQ); Voltage Sag; Voltage swell; Dynamic voltage restorer (DVR); PEM Fuel cell; ANFIS controller; Synchronous reference frame theory (SRF) algorithm.

\section{INTRODUCTION}

The development of power electronic based devices in the area of electrical power system has initiated an abundant awareness about PQ in distribution networks. Upgradation and automation of industry involve increasing usage of nonlinear devices, which can enhance Power Quality (PQ) issues, voltage sag, voltage swell, power interruptions, and harmonics. A recent survey suggests that voltage related PQ related events such as sag and swell (Khoshkbar Sadigh et al., 2016) have been attracting the eyes of researchers for decades, because they cause huge loss in productivity and profitability for both utilities and customers. This will increase the need for improving PQ in distribution systems (Ghosh A et al., 2002). Earlier, PQ problems have been addressed using traditional filters 
like active power filter; static synchronous compensator provides several issues such as tuning, resonance problem, and selection of frequency. Nowadays, many researchers focus on the usage of Custom Power Devices (CPD) (Hingorani NG, 1995) like STATCOM (Shadmand M B, 2017 \& Wesam Rohouma A, 2020) and DVR, because these devices are constructed using advanced power electronic technology, well suited for power quality improvement in a distribution system. STATCOM is proven as a suitable device (Bindeshwar Singh et al., 2018 \& Marcelo G , 2011) for harmonic and reactive power compensation in a distribution network. Dynamic Voltage Restorer (DVR) (Chinmay Deshpande et al., 2015, Himadri Ghosh et al., 2012 \& Ghosh A et al., 2014) is a CPD used for compensating voltage based PQ issues, particularly voltage sag and swell. The alleviation capacity of DVR is based on the magnitude of voltage injected from DVR and also its real power support to grid. Generally, battery energy storage (Jayaprakash P et al., 2014 \& Shi J et al., 2010) is used as an input for DVR to provide active power, but batteries are still bulky and costly and must be disposed once their chemicals are used, which limits the compensation capability of DVR. In recent years, the increase in consumption of energy has forced the researchers to focus more on Renewable Energy Sources (RES) (Ramasamy M et al., 2013 \& Dursun E et al., 2012). Though there are different RES available such as photovoltaic and wind energy, the potential techniques that can provide renewable energy are Fuel Cell (FC) technology [Bıyıkoglu Atilla , 2005], which is better than other renewable sources of energy. From the enormous renewable energy sources, Proton Exchange Membrane Fuel Cell (PEMFC) technology is considered by its greatly efficient energy storage, which has the potential to carry real power storage characteristic and also high power and energy density for short-term response. It provides noiseless operation and is also used as an input for DVR. Many researchers suggested different types of controllers (Srinivasa Rao N et al., 2018, Mehrdad Tarafdar Haghet al., 2018 \& P. Piramanathan et al., 2013) to enhance the performance of DVR. ANFIS controller has reduced fuzzy rules, which increases its speed of operation that can be identified, as well as suited (M. Nabipour et al., 2018), for making suitable reference value of voltage for DVR. The paper Bhavani R et al. (2018) uses ANFIS controller to enhance the performance of battery supported DVR. The main problem is the use of batteries as DC input, which limits its compensation capability, and the DVR input is not also maintained as constant. So, it is not suitable for deep PQ problems happening at very short duration of time.

This paper presents the simulation modeling of PEMFC-DVR, which includes a PEM fuel cell module as a DC source for DVR to suggest an advanced controller (SRF Theory along with ANFIS Controller) and improve the compensation ability of DVR. An appropriate DC-DC boost converter is modelled to provide the essential DC link voltage for DVR. A SRF control algorithm is well suited for unbalanced voltage sag and voltage swell issues. The proposed PEMFC DVR is demonstrated with various \% of balanced and unbalanced sag and swell events, and the Total Harmonic Distortion (THD) of the load side voltage is also greatly reduced as compared with conventional DVR.

\section{NOVELTY OF THE PROPOSED WORK}

Industries demand systems confirming uninterrupted transmission and distribution of power to quash their losses in terms of capital, income, and production. In conventional DVR, maintaining DC input voltage during compensation is a huge challenge, which improves its compensation capability. The technical innovation is to suggest a new topology for DVR by integrating PEM Fuel Cell as a DC input through DC-DC converter. An improved SRF control algorithm with ANFIS controller is modeled for PEMFC DVR for the mitigation of both balanced and unbalanced sag and swells PQ problems. The success of the PEMFC DVR using ANFIS controller was verified for different magnitudes of sag and swell problems. This will offer an improved controllability along with industrial electronics providing enormous growth opportunities for the world DVR markets. It also injects active power to the grid thus driving DVR markets. 


\section{PEMFC-DVR INTEGRATED SYSTEM}

The block diagram of PEMFC-DVR connected with distribution system is shown in Figure 1. Voltage related PQ issues of sag and swell are created by simulating fault in all three phases and addition of capacitive load, respectively, in a distribution system. DVR consists of Voltage Source Inverter (VSI), which injects an essential voltage to distribution grid in series to maintain the magnitude of load side voltage undisturbed. PEMFC stack is used as energy storage device and is connected as DC input for DVR.

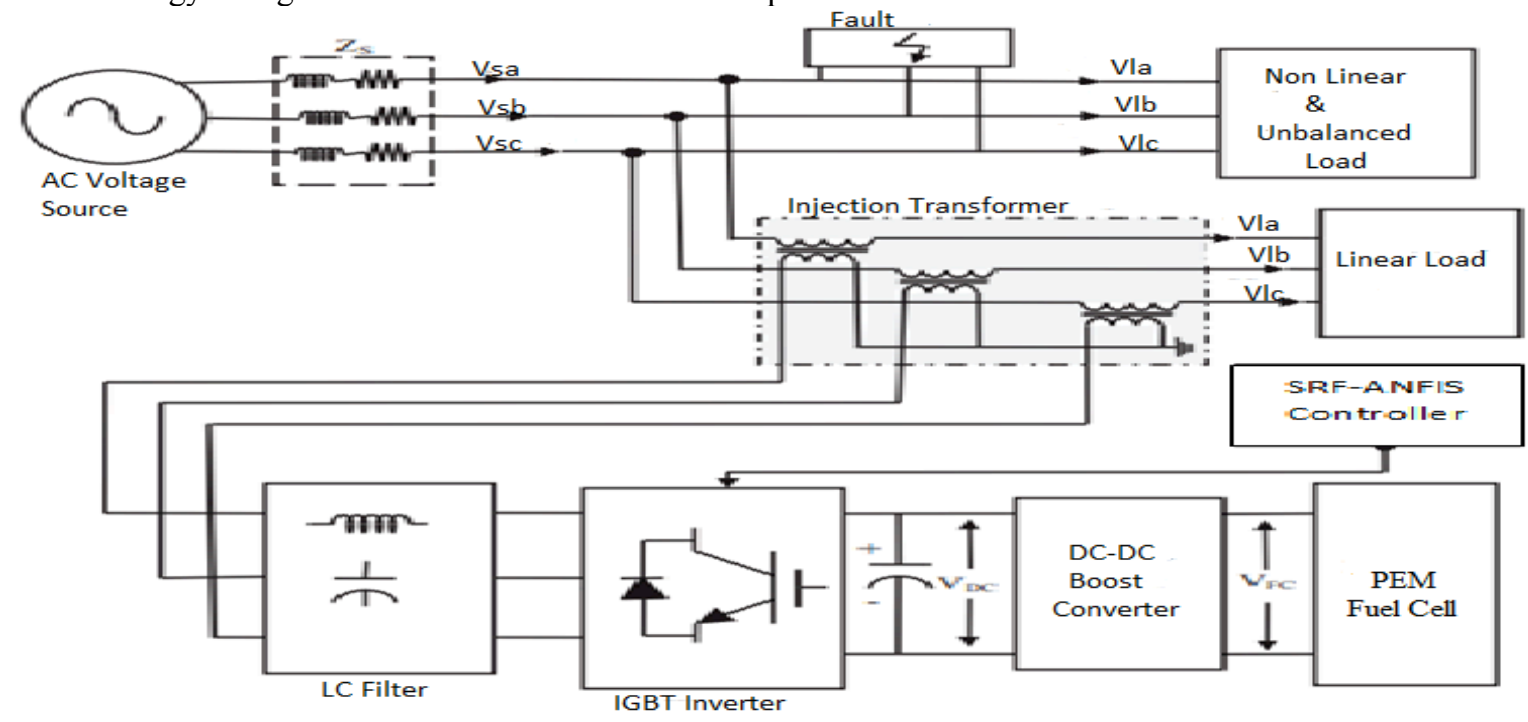

Figure 1. PEMFC integrated DVR System.

PEMFC-DVR is capable of mitigating very deep sag and swell, which occurs in a very short duration of time by adding appropriate voltage to the grid using injection transformer. The output voltage from PEMFC fuel cell is boosted using DC-DC converter to produce the suitable DC input voltage for DVR. PEMFC DVR is controlled using SRF algorithm with ANFIS controller.

\section{SIMULATION OF PEMFC STACK}

The diagrammatic representation of PEM Fuel Cell stack is shown in Figure 2. It consists of solid polymer electrolyte consisting of anode and cathode electrode separated by platinum catalyst membrane. The hydrogen atoms in anode electrode are immobilized into negative and positive ions. The positive ions are drifted through the membrane and absorbed by electrode (Cathode). It produces voltage when the electrons are moving towards the connected load, and voltage is produced. Inside the substance, the ions of both positive and negative charges are recombined, and the chemical reaction inside PEMFC is given by Equations 1-3.

$$
\begin{aligned}
& \mathrm{H}_{2}=2 \mathrm{H}^{+}+2 \mathrm{e}^{-} \\
& 1 / 2 \mathrm{O}_{2}+2 \mathrm{H}^{+}+2 \mathrm{e}^{-}=\mathrm{H}_{2} \mathrm{O} \\
& \mathrm{H}_{2}+1 / 2 \mathrm{O}_{2}=\mathrm{H}_{2} \mathrm{O}
\end{aligned}
$$




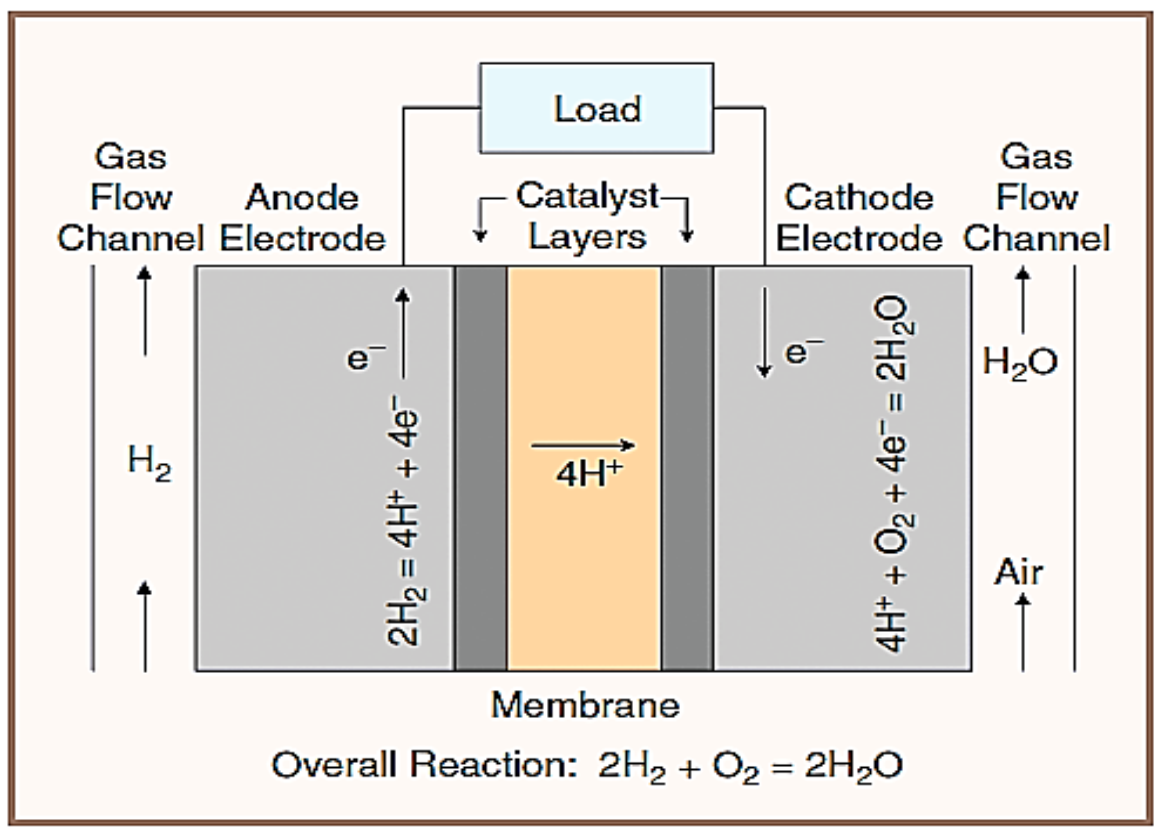

Figure 2. PEM Fuel Cell stack.

In fuel cell Stack, individual fuel cell is stacked to obtain the required voltage and power. Because of the chemical reaction inside fuel cell stack, layers are charged with opposite polarity around the boundary of the membrane and cathode. This forms double layers because of the electrochemical reaction, which stores electrical energy. Moreover, PEMFC stack is having long life and is suitable for short duration high power applications.

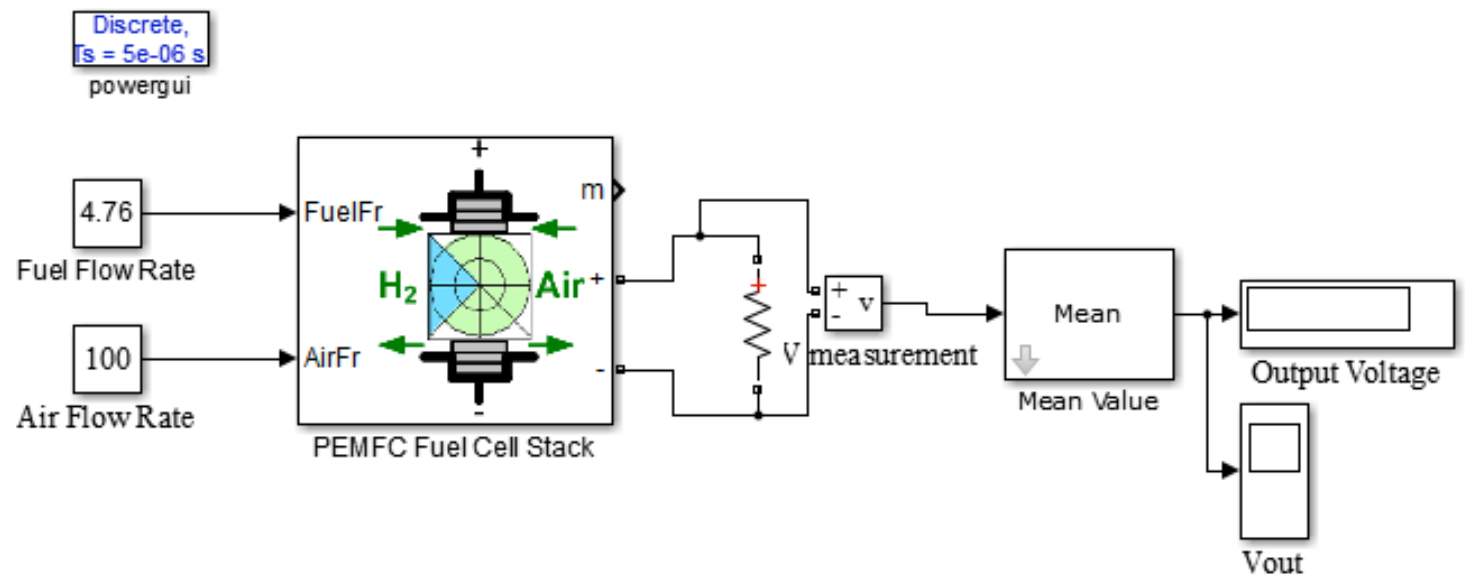

Figure 3. Simulink model of $6 \mathrm{KW} 45$ V PEMFC Stack.

The simulated PEM fuel cell model is shown in Figure 3. In this paper, 65 fuel cells are connected in series to get an output power of $6 \mathrm{~kW}$ with an output voltage of $45 \mathrm{~V}$. The core ingredients used inside fuel cell are oxygen and hydrogen. The fuel flow rate for the ingredients oxygen and hydrogen is chosen from the characteristics of PEM fuel cell for the output voltage of 45V. The output voltage obtained from PEM fuel cell is shown in Figure 4. 


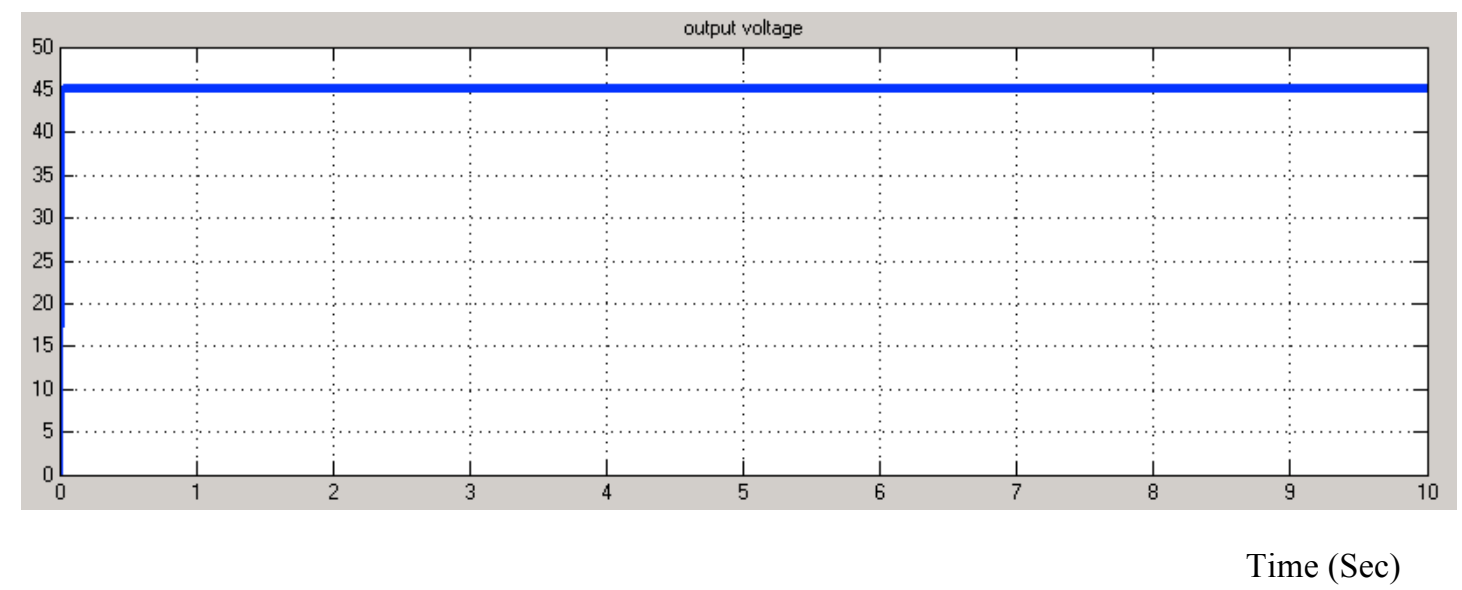

Figure 4. PEMFC output voltage.

For this $45 \mathrm{v}$, an appropriate DC-DC boost converter is modeled and simulated to produce the output voltage of $300 \mathrm{~V}$, suited to be used as DC link voltage for DVR.

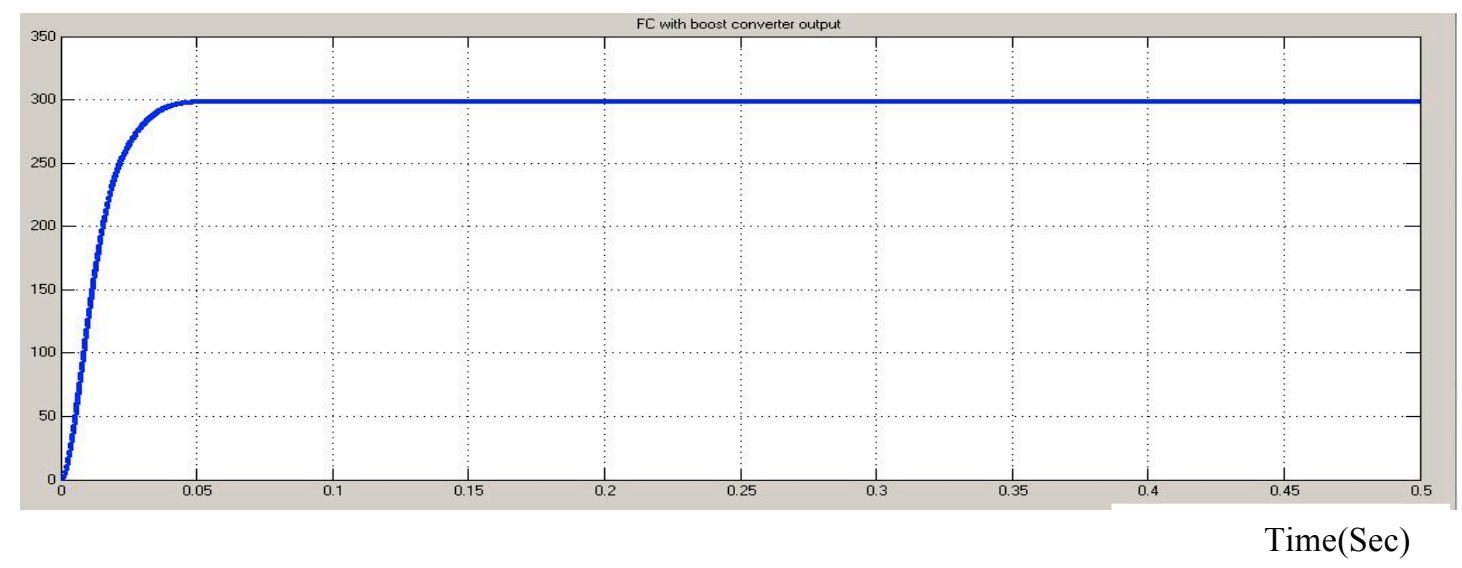

Figure 5. Boost Converter output voltage.

\section{SRF CONTROL ALGORITHM}

The control algorithm proposed for DVR can be used for compensating both balanced and unbalanced voltage related PQ problems. A suitable SRF algorithm is used to get the reference voltages for DVR. In this algorithm, the three phase load voltages are sensed continuously and then transformed to rotating frame using abc - dq0 transformation using Equation 4 to get the direct axis $\left(\mathrm{V}_{\mathrm{d}}\right)$ and quadrature axis $\left(\mathrm{V}_{\mathrm{q}}\right)$ components of load side voltages.

$$
\left[\begin{array}{c}
\mathrm{V}_{\mathrm{Tq}} \\
\mathrm{V}_{\mathrm{Td}} \\
\mathrm{V}_{\mathrm{T} 0}
\end{array}\right]=\frac{2}{3}\left[\begin{array}{ccc}
\cos \theta & \cos \left(\theta-\frac{2 \pi}{3}\right) & \cos \left(\theta+\frac{2 \pi}{3}\right) \\
\sin \theta & \sin \left(\theta-\frac{2 \pi}{3}\right) & \sin \left(\theta+\frac{2 \pi}{3}\right) \\
1 / 2 & 1 / 2 & 1 / 2
\end{array}\right]\left[\begin{array}{c}
\mathrm{V}_{\mathrm{Ta}} \\
\mathrm{V}_{\mathrm{Tb}} \\
\mathrm{V}_{\mathrm{Tc}}
\end{array}\right]
$$


Both terminal and load side voltages are synchronized using Phase Locked Loop (PLL). Low pass filter is used to generate DC components of voltages $\mathrm{V}_{\mathrm{d}}{ }^{*}$ and $\mathrm{V}_{\mathrm{q}}{ }^{*}$. The reference bus voltage $\mathrm{V}_{\mathrm{dc}}{ }^{*}$ is compared with real voltage $\left(\mathrm{V}_{\mathrm{dc}}\right)$, and the error voltage obtained is given as input to PI controller to generate the voltage loss component $\left(\mathrm{V}_{\text {loss }}\right)$. Further, it is added with $\mathrm{V}_{\mathrm{d}}$ * to produce $\mathrm{V}_{\mathrm{d}}$ '. The reference d-axis load voltage is obtained using the following equation:

$$
\mathrm{V}_{\mathrm{d}}^{*}=\mathrm{V}_{\mathrm{sd} \mathrm{dc}}-\mathrm{V}_{\text {loss }}
$$

The magnitude of load voltage is controlled by another PI controller, which produces var component of voltage $\left(\mathrm{V}_{\mathrm{qr}}\right)$ and is summed with $\mathrm{V}_{\mathrm{q}}$ to produce $\mathrm{V}_{\mathrm{q}}{ }^{*}$ using

$$
\mathrm{V}_{\mathrm{q}}^{*}=\mathrm{V}_{\mathrm{Tq} \mathrm{dc}}+\mathrm{V}_{\mathrm{qr}}
$$

The magnitude of the load voltage is computed using

$$
\mathrm{V}_{\mathrm{L}}=\sqrt{\left(\frac{2}{3}\right)\left(\mathrm{V}_{\mathrm{La}}^{2}+\mathrm{V}_{\mathrm{Lb}}^{2}+\mathrm{V}_{\mathrm{Lc}}^{2}\right)}
$$

The resultant three phase voltages are obtained using dq0-abc transformation using Equation 8 to produce the PWM switching pulses for VSC.

$$
\left[\begin{array}{c}
\mathrm{V}_{\mathrm{La}}^{*} \\
\mathrm{~V}_{\mathrm{Lb}}^{*} \\
\mathrm{~V}_{\mathrm{Lc}}^{*}
\end{array}\right]=\left[\begin{array}{ccc}
\cos \theta & \cos \left(\theta-\frac{2 \pi}{3}\right) & \cos \left(\theta+\frac{2 \pi}{3}\right) \\
\sin \theta & \sin \left(\theta-\frac{2 \pi}{3}\right) & \sin \left(\theta+\frac{2 \pi}{3}\right) \\
1 / 2 & 1 / 2 & 1 / 2
\end{array}\right]\left[\begin{array}{c}
\mathrm{V}_{\mathrm{Lq}}^{*} \\
\mathrm{~V}_{\mathrm{Ld}}^{*} \\
\mathrm{~V}_{\mathrm{L} 0}^{*}
\end{array}\right]
$$

\section{ANFIS CONTROLLER}

ANFIS is a combination of neurofuzzy system that gets the learning capability of neural networks to Fuzzy Inference Systems (FIS) to give enhanced Fuzzy Inference System (FIS). It uses input-output training data along with learning algorithm to modify the membership functions of FIS. ANFIS makes use of combined learning rule and handles complicated nonlinear systems. ANFIS has been recognized as an efficient tool for the modification of the membership functions of FIS. The ANFIS controller architecture is shown in Figure 6. 


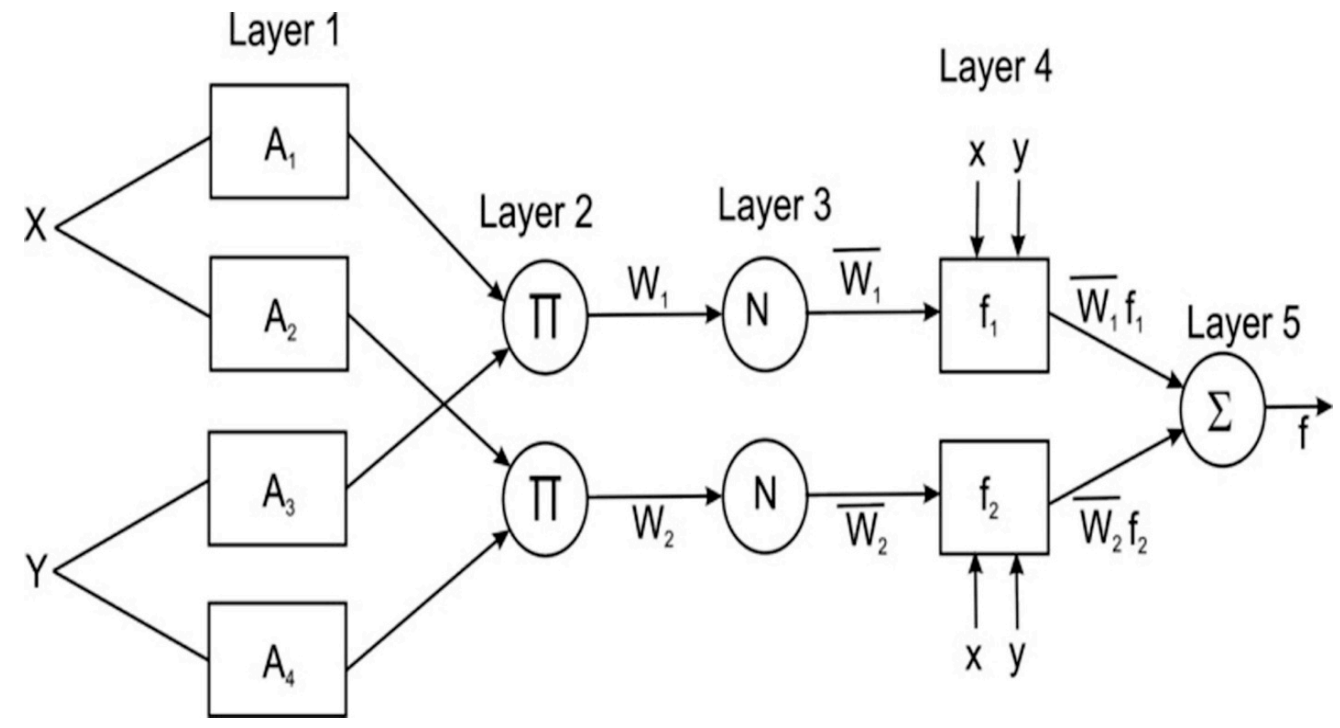

Figure 6. ANFIS controller architecture.

Layer 1 shows the relation between input variables (X, Y) and fuzzy membership functions (A1, A2, A3, A4). Layer 2 represents the product of incoming signals, which shows the strength of fuzzy rule to be fired. Layer 3 is used to calculate controlled strength of each rule to be fired by using weights (W1, W2). Layer 4 represents Fuzzy Inference System, which uses input variable to form fuzzy rules. Layer 5 shows defuzzification process, producing the output of ANFIS controller. Table 1 shows the rule base representation used in ANFIS controller. The FIS makes use of these rules to produce the essential output.

Table 1. Rule Base Representation.

\begin{tabular}{|c|l|l|l|l|l|l|l|}
\hline $\begin{array}{c}\mathrm{e} \\
\mathrm{e}\end{array}$ & $\mathrm{NB}$ & $\mathrm{NM}$ & $\mathrm{NS}$ & $\mathrm{Z}$ & $\mathrm{PS}$ & PM & PB \\
\hline NB & NB & NB & NB & NM & NM & NS & Z \\
\hline NM & NB & NB & NM & NM & NS & Z & PS \\
\hline NS & NB & NM & NM & NS & Z & PS & PM \\
\hline Z & NM & NM & NS & Z & PS & PM & PM \\
\hline PS & NM & NS & Z & PS & PM & PM & PB \\
\hline PM & NS & Z & PS & PM & PM & PB & PB \\
\hline PB & Z & PS & PM & PM & PB & PB & PB \\
\hline
\end{tabular}

In this paper, PEMFC DVR is interconnected with the distribution system using SRF-ANFIS controller. The training data of error voltage and change in error voltage were acquired using SRF-FUZZY Logic controller. These data are defined using 7 linguistic variables (NB, NM, NS, Z, PS, PM, and PB), where $\mathrm{N}=$ Negative Big, NM =Negative Medium, NS-Negative Small, Z- Zero, PS = Positive Small, PM-Positive Medium, and PB-Positive Big are shown in Table I. From these variables, 49 rules are constructed using triangular membership functions to model Sugeno type FIS. The parameters of the membership functions are controlled using the hybrid back propagation learning algorithm. The inputs to ANFIS Controller are modeled using 


$$
\begin{aligned}
& \mathrm{e}(\mathrm{k})=\mathrm{V}_{\text {ref }}-\mathrm{V}_{\mathrm{t}} \\
& \Delta \mathrm{e}(\mathrm{k})=\mathrm{e}(\mathrm{k})-\mathrm{e}(\mathrm{k}-1)
\end{aligned}
$$

where $\mathrm{V}_{\text {ref }}$ is the reference Voltage, and $\mathrm{V}_{\mathrm{t}}$ is the terminal voltage. $\mathrm{e}(\mathrm{k})$ and $\Delta \mathrm{e}(\mathrm{k})$ are the error and change in error, respectively. The input and output membership functions are shown in Figure 7(a-c).

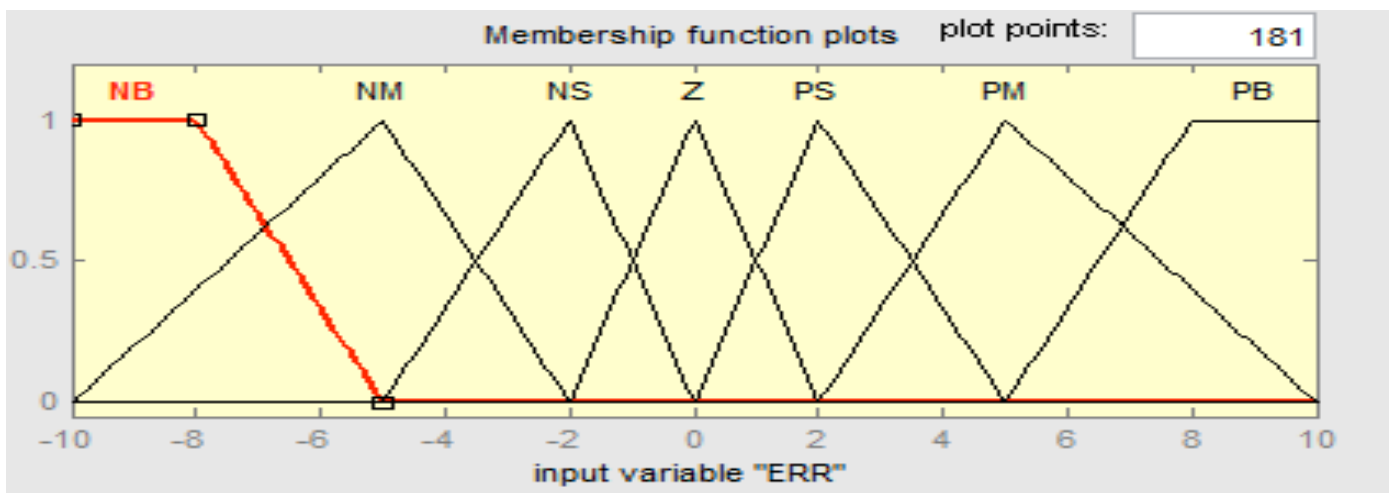

(a)

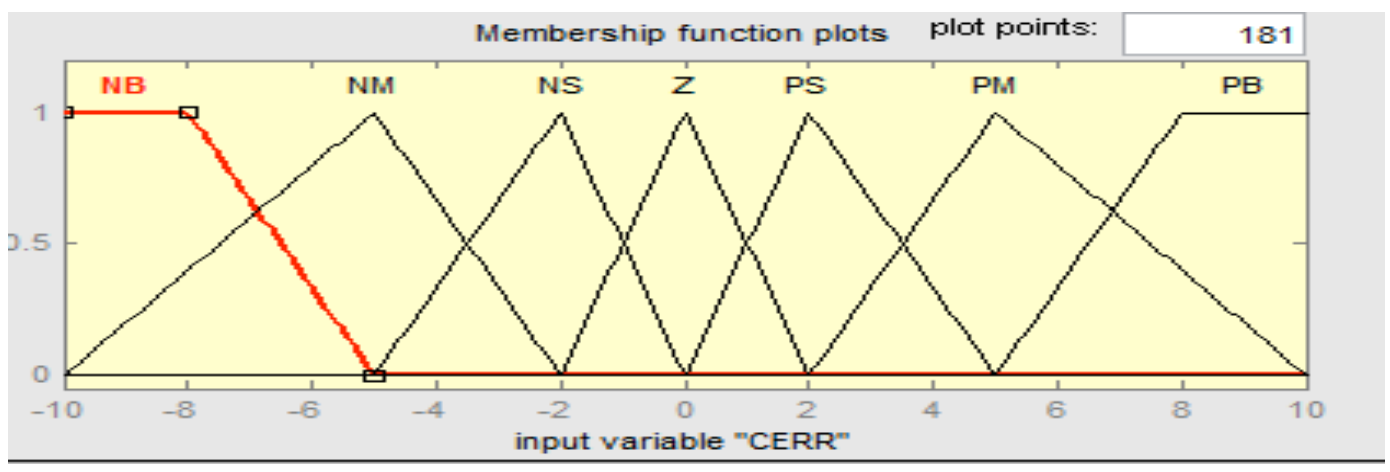

(b)

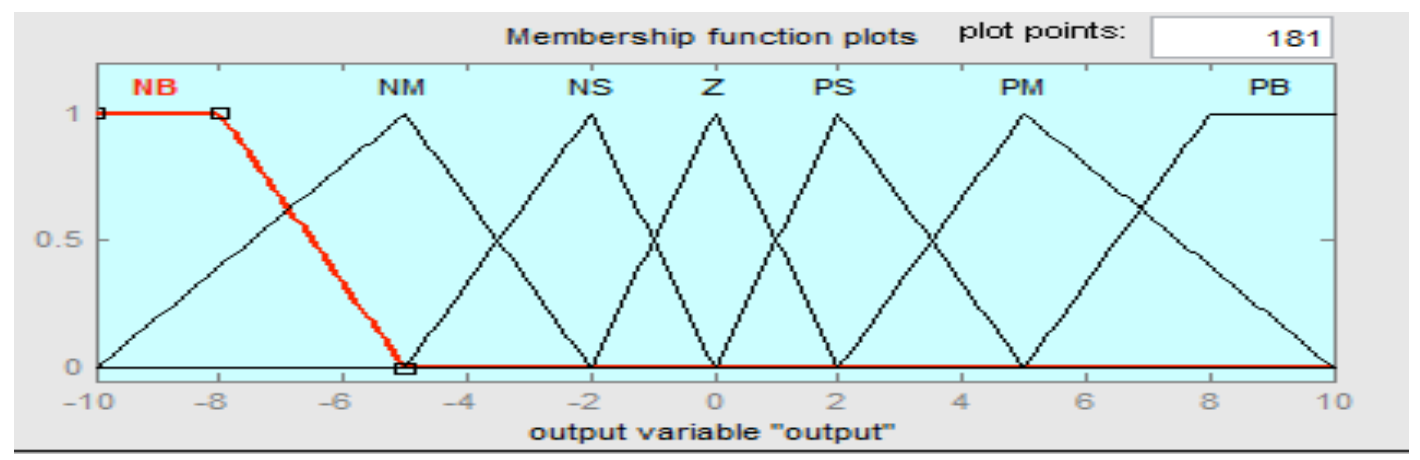

(c)

Figure 7. Membership functions for (a) error, (b) change in error, and (c) output. 
A total of 100 epochs are chosen with a training error of 0.01 . Figure 8 shows the MATLAB simulated output structure for ANFIS controller, and Figure 9 shows the output of ANFIS controller for training.

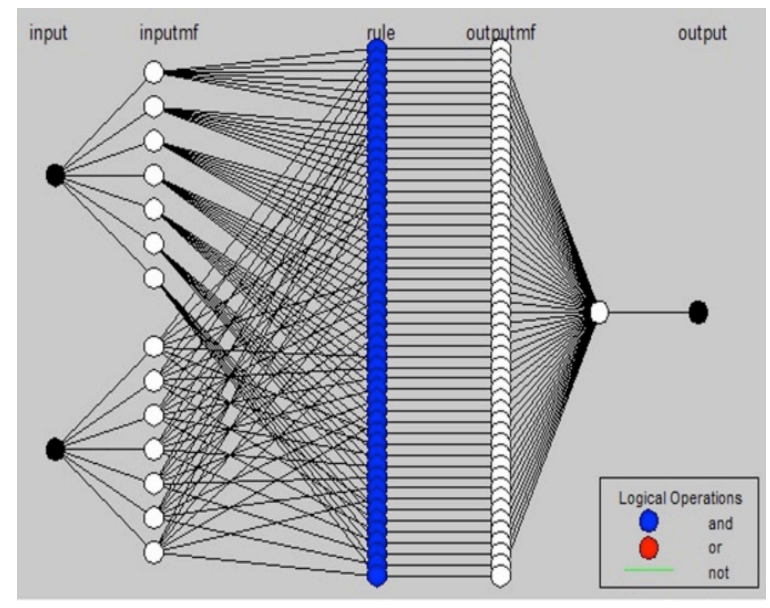

Figure 8. Simulated ANFIS Structure.

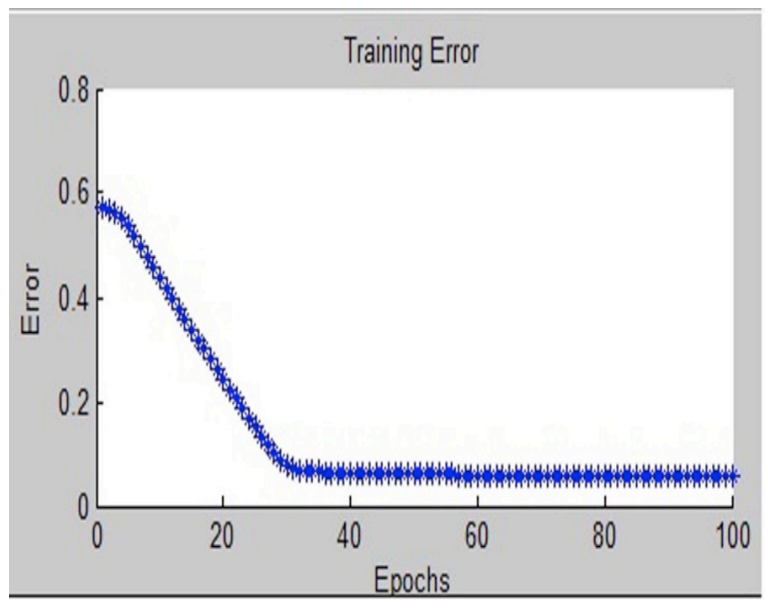

Figure 9. Error Vs Epochs.

\section{SIMULATION RESULTS}

Consider a $415 \mathrm{~V}, 50 \mathrm{~Hz}$ three-phase distribution system connected to linear load of $15 \mathrm{MVA}, 0.8 \mathrm{PF}$ with line impedance $L_{s}=3 \mathrm{mH}, \mathrm{R}_{\mathrm{s}}=0.01 \Omega$. Voltage sag and swell are simulated by creating fault at all three phases to ground, with the addition of capacitive load for three phases within the time duration of $0.2 \mathrm{~s}$ to $0.4 \mathrm{~s}$, respectively. The PEMFC DVR consists of 45V PEMFC stack, DC-DC boost converter, Voltage source inverter (VSI), and injection transformer modeled and integrated with distribution system. The reference voltages for PEMFC DVR are calculated using SRF ANFIS controller to enhance its compensation capability against voltage sag and voltage swell issues. The PEMFC DVR is modeled and interconnected with distribution system using SRF ANFIS controller in MATLAB as shown in Figure 10. 


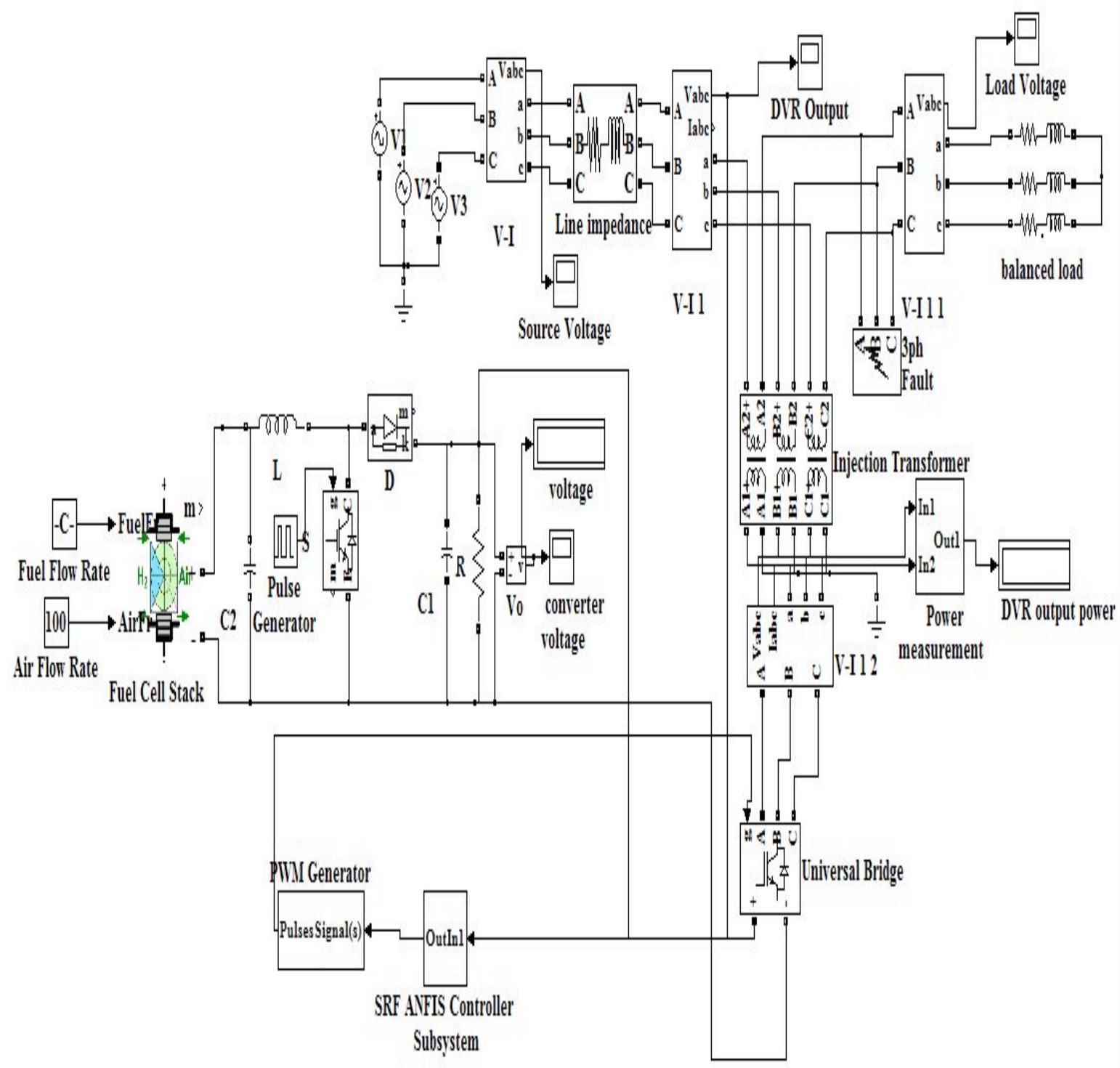

Figure 10. PEMFC DVR connected with distribution system using SRF ANFIS Controller.

Figure 11 shows the Simulink model of SRF-ANFIS controller. In this algorithm, the sensed load voltages are converted to rotating reference frame (d-q) using parks transformation with unit vectors derived from Phase Locked Loop (PLL). The dqo transformation gives the sag depth and phase shift information with start and end times. It also eliminates zero phase sequence components. The error between the reference and actual DVR voltages in the rotating reference frame is regulated using one ANFIS controller. The input to another ANFIS controller is the error between reference DC voltage and the sensed DC voltage used to regulate the DC bus voltage of DVR. 


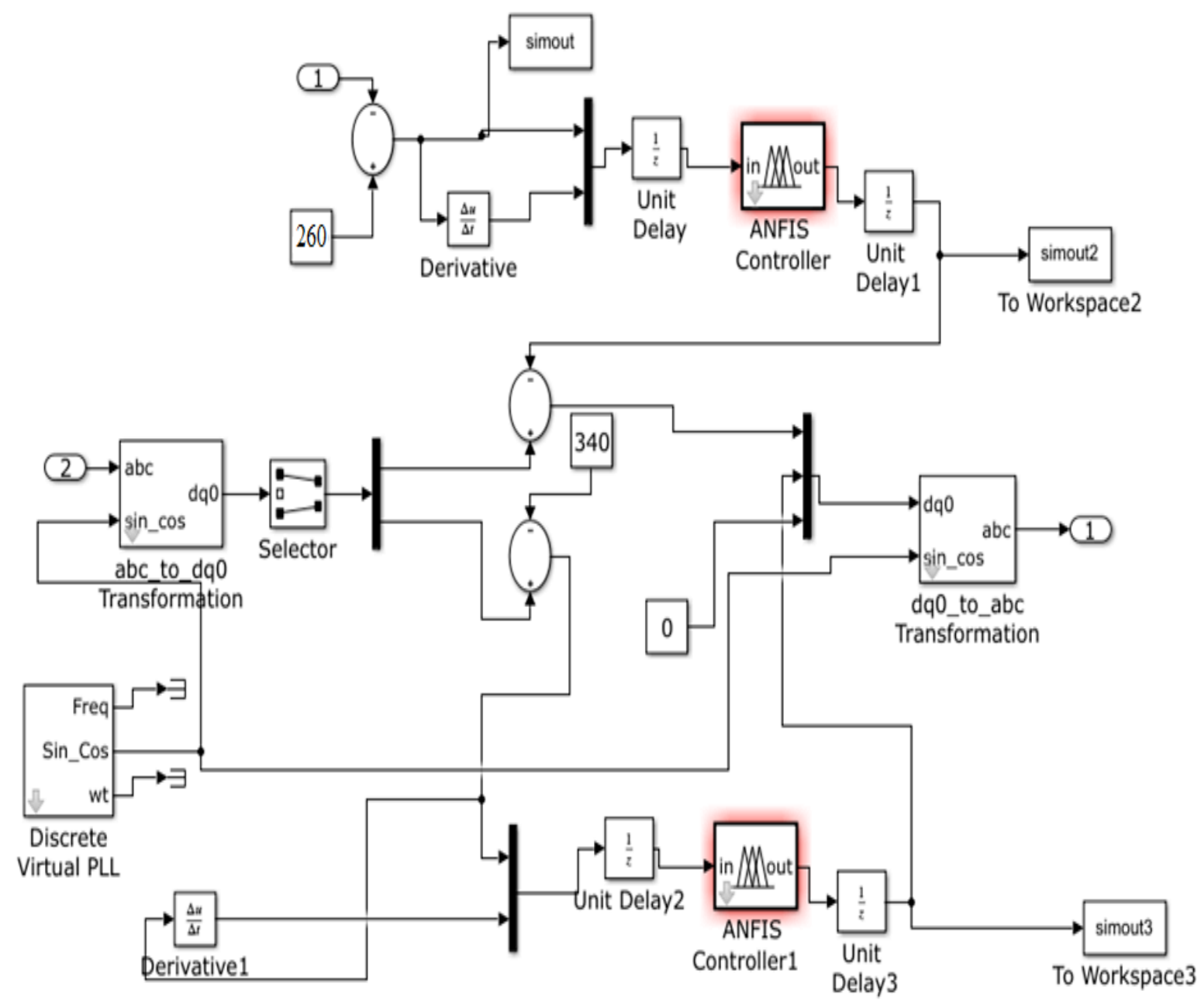

Figure 11. Simulink Model of SRF Control Algorithm.

The resultant output is given as PWM controller to generate gating pulses to a VSI so as to produce threephase $50 \mathrm{~Hz}$ sinusoidal voltage at the load terminal. The switching frequency of PWM controller is $10 \mathrm{kHz}$.DVR dc-link voltages $340 \mathrm{~V}$. The compensation capability of PEMFC DVR is verified for various $\%$ of sag and swells events using SRF- PI and SRF-ANFIS controller. Both unbalanced and balanced sag voltages are simulated by creating Single Line to Ground (SLG) Fault, Double Line to Ground (DLG) Fault, and balanced 3-phase Fault in a three-phase distribution system. The transient performance of DVR for the problem of voltage sag is shown in Figure 12(a-d). Three-phase $90 \%$ balanced voltage sag is created for the duration of 0.2 to $0.4 \mathrm{sec}$ by simulating three phases to ground fault in the distribution system. Simultaneously, DVR gets activated at $0.2 \mathrm{sec}$ and also injects required $290 \mathrm{~V}$, which is in phase with load voltage shown in Figure 12(c), thus restoring the magnitude of load voltage. Thus, the load voltage magnitude is retained constant. 


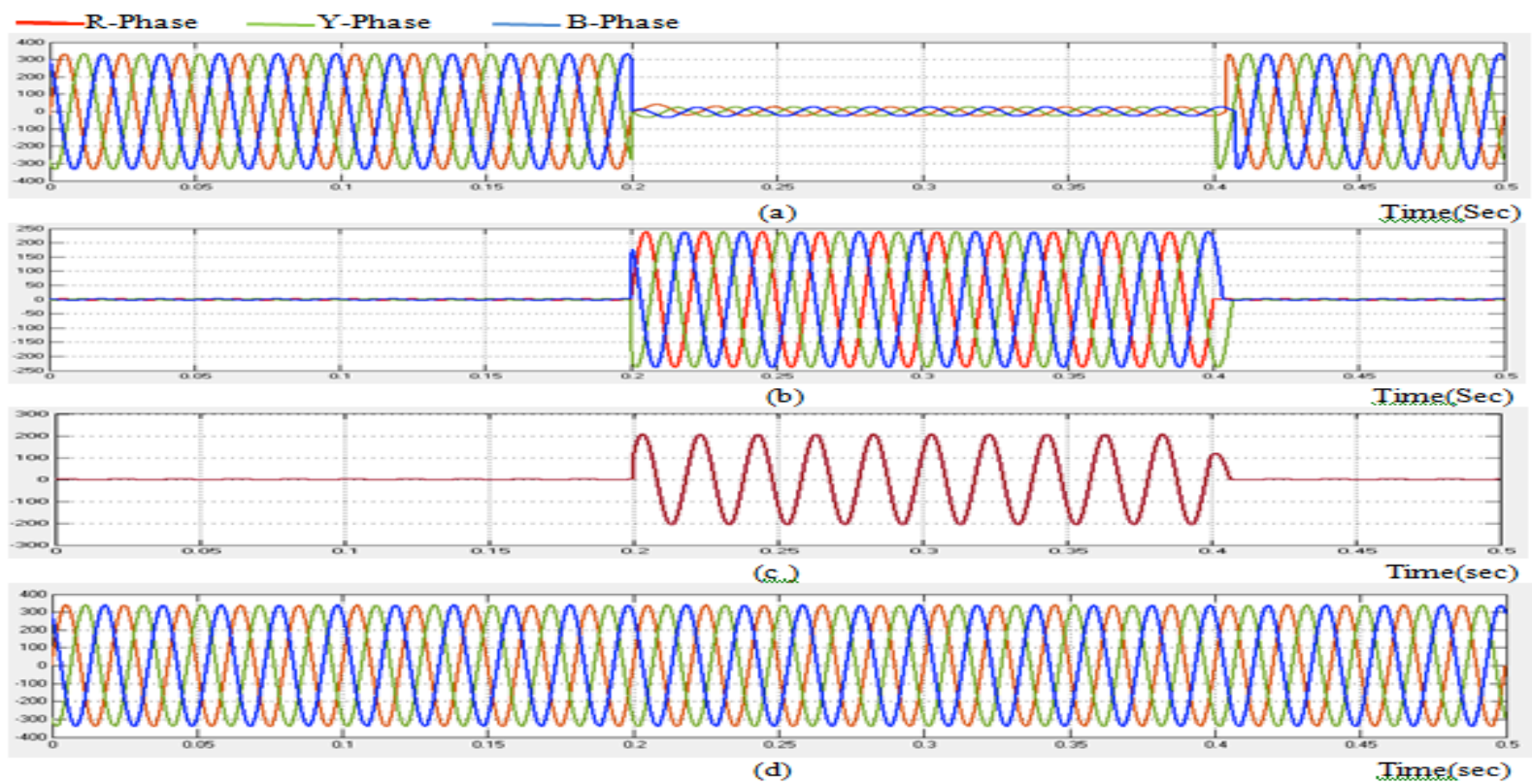

Figure 12. Performance of DVR for voltage sag. a) Sag. b) DVR injected Voltage.

(c) DVR injected Voltage (R-phase). (d) Compensated output voltage. 13(a-d).

During swell event, the DVR injected voltage for all three phases (Vinja, Vinjb, Vinjc) is shown in Figure

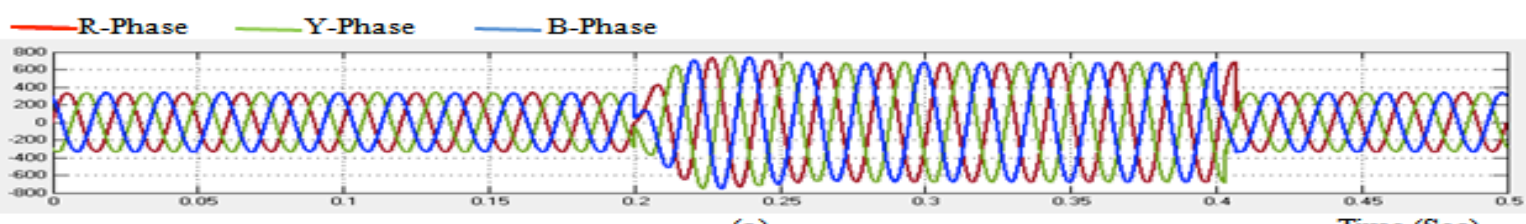

(a)

Time (Sec)

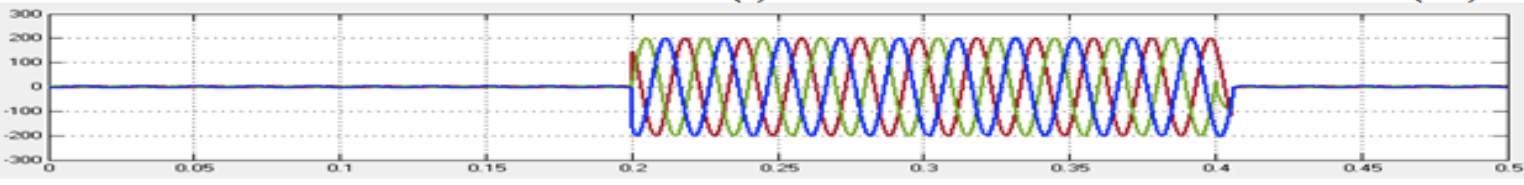

(b)

Time (Sec)
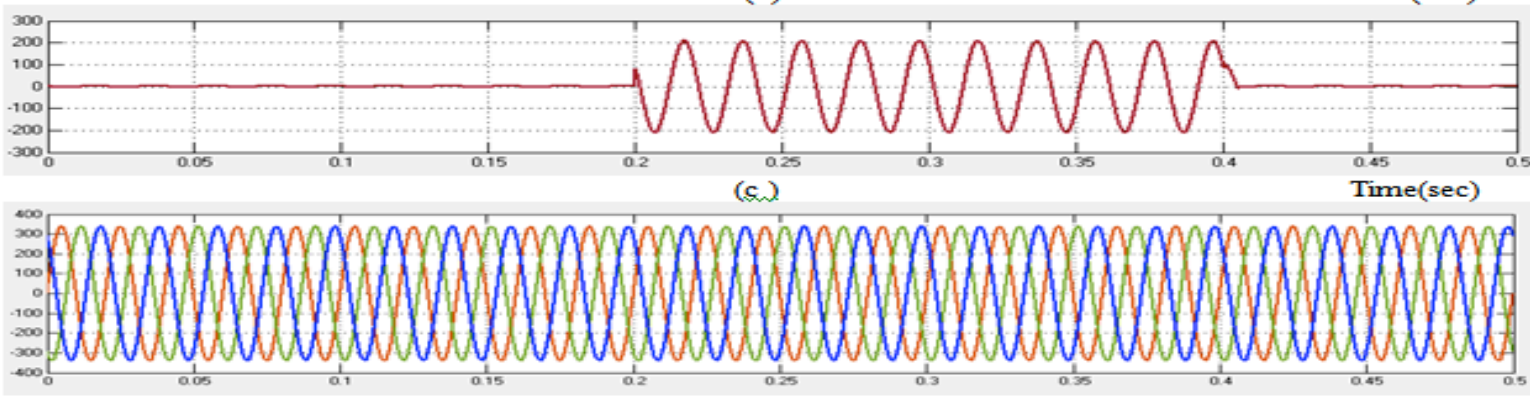

(d)

Times(sec)

Figure 13. Performance of DVR for voltage swell: a) swell. b) DVR absorbed Voltage. (c) DVR absorbed Voltage (R phase). (d) Compensated output voltage. 
For this, $85 \%$ of swell event is created by the addition of capacitive load in the distribution system for the duration of $0.2 \mathrm{sec}$ to $0.4 \mathrm{sec}$, and results increase in load voltage from $340 \mathrm{~V}$ to $630 \mathrm{~V}$. Simultaneously, DVR gets activated at $0.2 \mathrm{sec}$ and also injects required $290 \mathrm{~V}$, which is in opposite phase with load voltage, thus restoring the magnitude of load voltage. Thus, the load voltage magnitude is retained constant.

The proposed DVR was also tested for unbalanced sag event. This event is simulated in a three-phase distribution system by two phases to ground fault for the duration of 0.2 to $0.4 \mathrm{sec}$. The DVR performance for this unbalanced sag event for the problem of two phases to ground fault is shown in Figure 14(a-c).

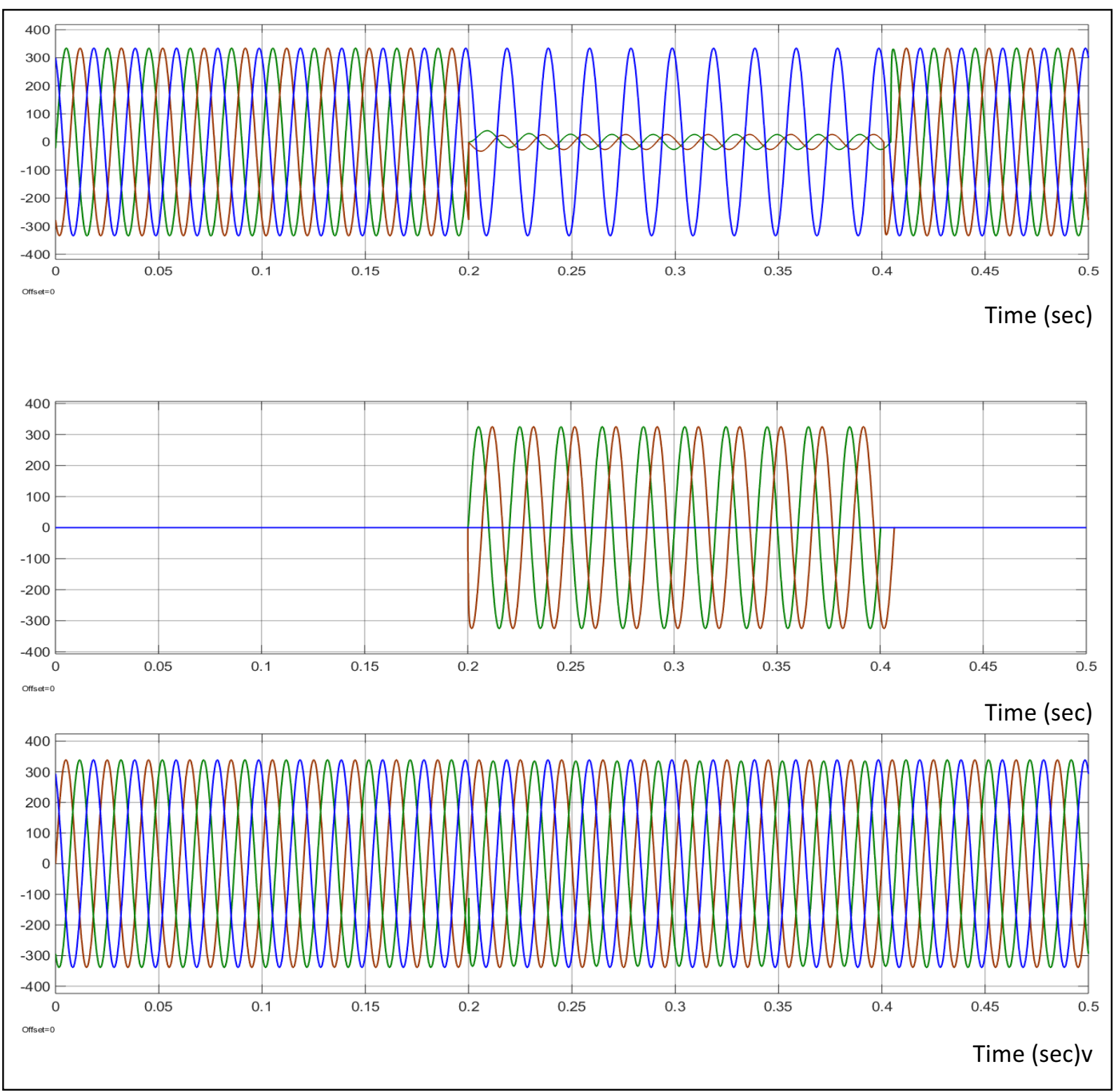

Figure 14. Performance of DVR for a) unbalanced sag. b) DVR output voltage. (c) Compensated load voltage. 
Unsymmetrical swell event is simulated in a three-phase distribution system by adding capacitive load at one phase and two phases for the duration of 0.2 to $0.2 \mathrm{sec}$. The output results are obtained for unsymmetrical swell event for the addition of capacitive load at two phases, and the corresponding DVR output voltage and the compensated load voltage are shown in Figures 15(a-c).

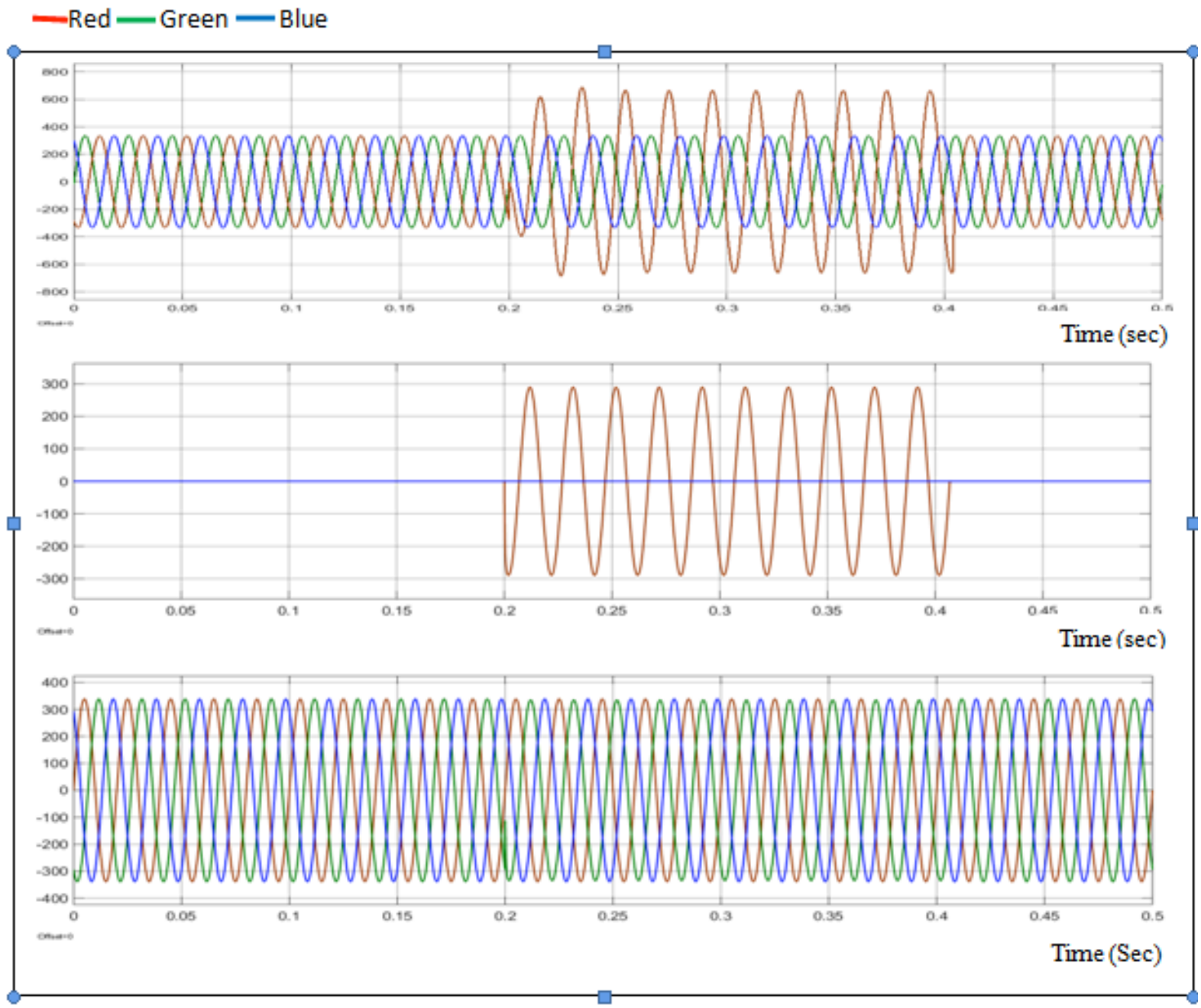

Figure 15. Performance of DVR for a) unbalanced swell. b) DVR output voltage. c) Compensated load voltage.

For different $\%$ of sag events, the $\%$ of compensated output load voltage obtained is also observed using SRFPI, and the SRF-ANFIS controllers are shown in Table 2. Table 3 shows the performance comparison of SRF-PI and SRF-ANFIS controller DVR compensation for $40 \%$ voltage swell event. It proves that the proposed DVR injects appropriate voltage magnitude for the problem of voltage sag and absorbs the required voltage magnitude for the problem of voltage swell, thus maintaining reference voltage by giving superior compensation. 
Table 2. DVR output for voltage sag.

\begin{tabular}{|c|c|c|c|c|c|c|c|c|c|}
\hline \multirow{2}{*}{$\begin{array}{l}\% \text { of } \\
\text { Sag } \\
\text { Event }\end{array}$} & \multicolumn{3}{|c|}{$\begin{array}{l}\% \text { of Load Voltage } \\
\text { Before Injection }\end{array}$} & \multicolumn{3}{|c|}{$\begin{array}{l}\% \text { of Load Voltage After } \\
\text { Injection SRF-PI Controller }\end{array}$} & \multicolumn{3}{|c|}{$\begin{array}{c}\% \text { of Load Voltage After } \\
\text { Injection SRF-ANFIS } \\
\text { Controller } \\
\end{array}$} \\
\hline & A & $\mathrm{B}$ & $\mathrm{C}$ & A & B & $\mathrm{C}$ & A & B & $\mathrm{C}$ \\
\hline \multicolumn{10}{|c|}{ SLG Fault } \\
\hline 30 & 106.5 & 70.0 & 106.4 & 103.3 & 101.4 & 103.5 & 100.2 & 100.1 & 100.3 \\
\hline 60 & 106.3 & 40.6 & 106.5 & 104.2 & 101.2 & 104.3 & 100.2 & 100 & 100.1 \\
\hline 90 & 106.4 & 10.6 & 106.7 & 104.5 & 101.7 & 104.2 & 100 & 100.1 & 100 \\
\hline \multicolumn{10}{|c|}{ DLG Fault } \\
\hline 30 & 105.5 & 70.9 & 70.6 & 104.4 & 103.8 & 101.5 & 100.2 & 100 & 100.1 \\
\hline 60 & 105.3 & 40.6 & 40.5 & 104.3 & 104.8 & 101.7 & 99.9 & 100 & 100 \\
\hline 90 & 105.7 & 10.7 & 10.8 & 103.4 & 103.8 & 101.9 & 100.2 & 100 & 99.8 \\
\hline \multicolumn{10}{|c|}{3 Phase to Ground fault } \\
\hline 30 & 70.7 & 70.7 & 70.5 & 102.3 & 101.9 & 102.6 & 100 & 100.1 & 100.3 \\
\hline 60 & 40.6 & 40.5 & 40.8 & 103.2 & 102.9 & 102.8 & 100.2 & 100 & 100.1 \\
\hline 90 & 10.7 & 10.6 & 10.8 & 101.7 & 102.3 & 102.6 & 100 & 100.1 & 100 \\
\hline
\end{tabular}

Table 3. DVR Output for voltage swell.

\begin{tabular}{|c|c|c|c|c|c|c|c|c|c|c|}
\hline \multirow{2}{*}{$\begin{array}{c}\text { \% of } \\
\text { Swell }\end{array}$} & \multicolumn{3}{|c|}{$\begin{array}{c}\text { \% of Load Voltage } \\
\text { Before Injection }\end{array}$} & \multicolumn{2}{c|}{$\begin{array}{c}\text { \% of Load Voltage } \\
\text { After Injection } \\
\text { SRF-PI Controller }\end{array}$} & \multicolumn{3}{c|}{$\begin{array}{c}\text { \% of Load Voltage } \\
\text { After Injection } \\
\text { SRF-ANFIS Controller }\end{array}$} \\
\cline { 2 - 11 } & A & B & C & A & B & C & A & B & C \\
\hline \multicolumn{8}{|c|}{ Balanced Voltage swell } \\
\hline $40 \%$ & 140.8 & 140.3 & 140.8 & 99.3 & 102.3 & 99.2 & 100.2 & 99.9 & 100.1 \\
\hline
\end{tabular}

The Total Harmonic Distortion (THD) obtained under various levels of sag voltage with $40 \%$ of sag and swell event for before and after compensation using different controllers is also tabulated in Table 4.

Table 4. Controllers Performance Comparison -Sag \& Swell.

\begin{tabular}{|c|c|c|c|}
\hline \multirow{2}{*}{ Types of Fault } & \multicolumn{3}{|c|}{ \% of THD } \\
\cline { 2 - 4 } & $\begin{array}{c}\text { Uncompensated } \\
\text { System }\end{array}$ & SRF-PI Controller & SRF-ANFIS Controller \\
\hline SLG & 15.7 & 1.65 & 1.23 \\
\hline DLG & 16.9 & 2.53 & 1.45 \\
\hline 3 Phase to Ground & 27.6 & 2.79 & 1.36 \\
\hline swell & 33.4 & 3.54 & 1.42 \\
\hline
\end{tabular}


From this, it is observed that the proposed PEMFC DVR compensates very deep sag and swell problems. In addition, the integration of Fuel Cell as DC input for DVR eliminates the drawback of battery supported DVR, and the controller suggested enhances its compensation capability. Thus, the proposed DVR gives a very good economical resolution for voltage related PQ problems. The Total Harmonics Distortions (THDs) spectrum of the load voltage obtained for both sag and swell event is shown in Figure 15, greatly reduced to the acceptable value.

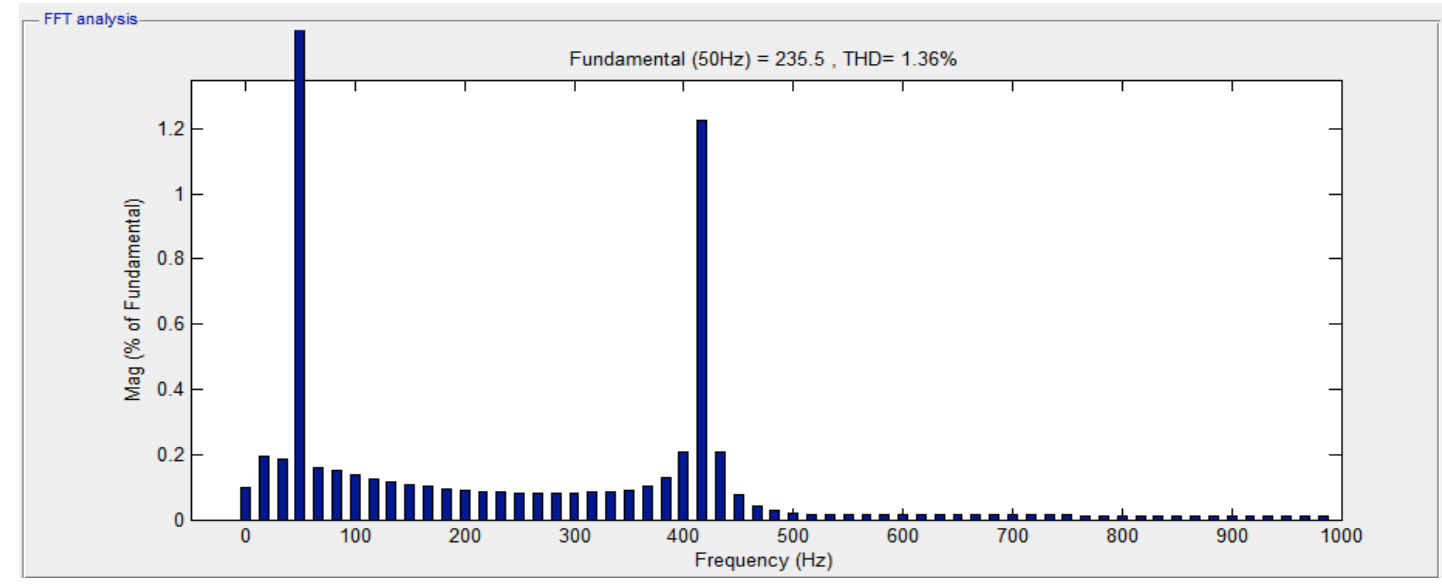

(a)

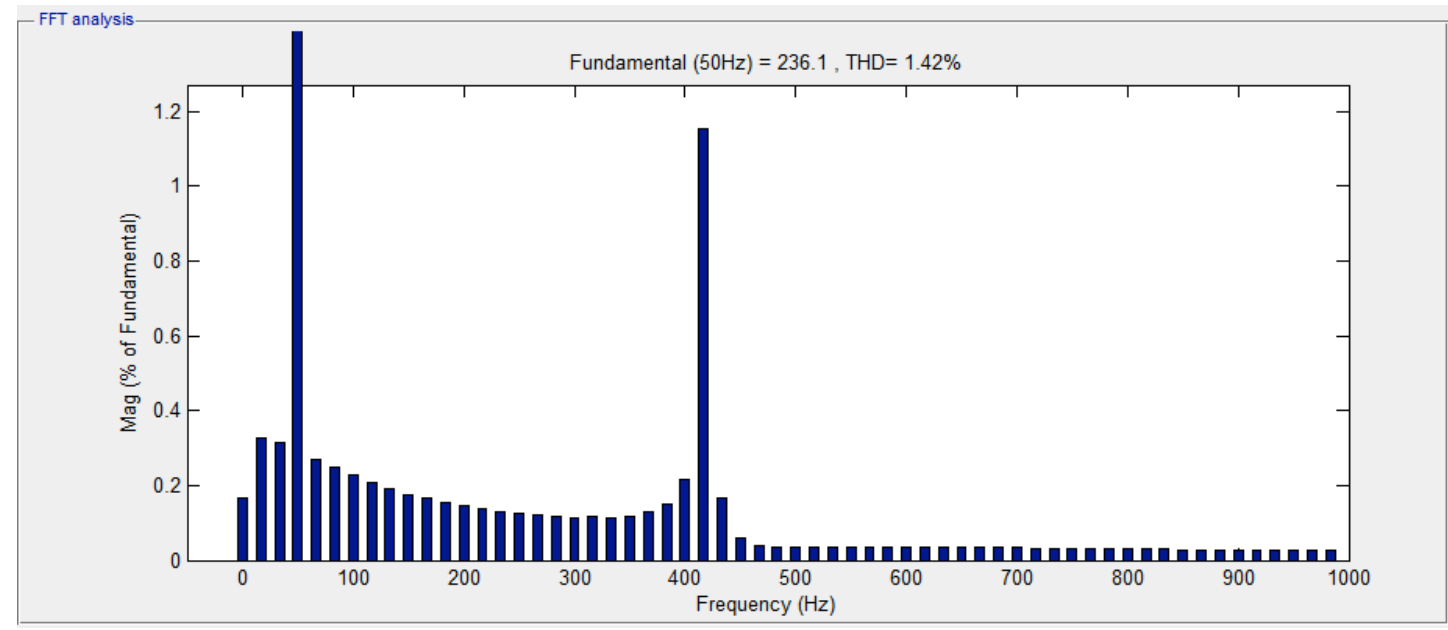

(b)

Fig. 15. Harmonic Spectrum of load voltage after compensation. a) sag; b) swell.

\section{CONCLUSION}

In this paper, the proposed PEM Fuel Cell Stack is successfully modeled and interconnected as a DC input for conventional DVR using DC-DC boost converter for the compensation of voltage related PQ problems in a distribution system. The PEM Fuel cell is proven as a valuable substitute for DC input of DVR. It has a capability of providing high power within a short period of time, which can overcome the energy storage limitations of 
conventional DVR. The DVR reference voltages were calculated using Synchronous Reference Frame (SRF) theory, which reduces the error of magnitude of DVR injected voltage. The effectual performances of PEMFCDVR are verified under different percentages of sag and swell issues. It can be observed that the SRF-ANFIS controlled PEMFC DVR effectively decreases the THD of the load voltage as compared to SRF-PI controlled DVR. The result obtained from simulation demonstrates that the SRF-ANFIS controller compensates balance and unbalanced voltages sags and swell problems. From the performance analysis, it is proven that the proposed PEMFC-DVR is capable of mitigating temporary voltage sag and swell problems and also offers active power support to grid.

\section{REFERENCES}

Khoshkbar Sadigh, K.M., Smedley. 2016. Fast and precise voltage sag detection method for dynamic voltage restorer application. Electric Power Systems Research. 130: 192-201.

Ghosh A. \& Ledwich G. 2002. Power quality enhancement using custom power devices. Boston Kluwer Academic Publishers.

Hingorani NG. 1995. Introducing custom power. IEEE Spectrum. 32 (6):41-83.

M.B. Shadmand, M. Mosa, R.S. Balog, H., Abu-Rub. 2017. Model predictive control of a capacitorless matrix converter-based STATCOM. IEEE IEEE Journal of Emerging and Selected Topics in Power Electronics. 5 (2): 796-808.

Wesam Rohouma A, Robert S., Balog, Aaqib Ahmad Peerzada, Miroslav M. Begovic. 2020. D-STATCOM for harmonic mitigation in low voltage distribution network with high penetration of nonlinear loads. Renewable Energy. 145: 1449-1464.

Bindeshwar Singh, Manish Kumar Yadav. 2018. GA for enhancement of system performance by DG incorporated with D-STATCOM in distribution power networks, Journal of Electrical Systems and Information Technology. 5: 388-426.

Marcelo G., Molinaa, N., Pedro E., Mercadoa, Edson H., Watanabeb. 2011. Analysis of integrated STATCOM-SMES based on three-phase three-level multi-pulse voltage source inverter for high power utility applications. Journal of the Franklin Institute 348: 2350-2377.

Babaei Ebrahim., Kangarlu Mohammad Farhadi. 2012. Sensitive load voltage compensation against voltage sags/swells and harmonics in the grid voltage and limit downstream fault currents using DVR. Electric Power Systems Research. 83(1): 80-90.

Chinmay Deshpande., Chaitanya Deshpande., Patil RJ. 2015. Voltages sag and swell mitigation using dynamic voltage restorer. International Journal of Advanced Research Science Engineering. 4(4).

Omar R., Rahim NA., Ahmad A. 2012: Voltage swells improvement in low voltage network using dynamic voltage restorer. American Journal of Applied Science. 8(1): 55-62.

Sharanya M., Basavaraja B., Sasikala M. 2012. An overview of dynamic voltage restorer for Voltage profile improvement. International Journal of Eng. Advanced Technology.. 2(2).

Himadri Ghosh., Pradip Kumar Saha. \& Goutam Kumar Panda. 2012. Design and Simulation of a Novel Self Supported Dynamic Voltage Restorer for Power Quality Improvement. International Journal of Electric Power Energy Systems. 3(6): 2229-5518.

Ghosh A., Jindal AK. \& Joshi A. 2014: Design of a capacitor-supported dynamic voltage restorer (DVR) for unbalanced and distorted loads. IEEE Trans Power Delivery. 19(1): 405-413.

Jayaprakash, P., Singh, B., Kothari, D.P., Chandra, A. \& Al-Haddad, K.2014. Control of Reduced-Rating Dynamic Voltage Restorer with a Battery Energy Storage System. IEEE Transactions on Industry Applications, 50: 1295-1303 .

Shi, J., Tang, Y.J., Yang, K., Chen, L., Ren, L., Li, J.D. \& Cheng, S.J. 2010. SMES Based Dynamic Voltage Restorer for Voltage Fluctuations Compensation. IEEE Transactions on Applied Superconductivity. 20: 31203130 . 
Omar R. \& Rahim NA. 2013. Voltage unbalanced compensation using dynamic voltage restorer based on super capacitor. International Journal of Electric Power Energy System. 12 : 43-573.

Ramasamy M., Thangavel S. 2013. Experimental verification of PV based dynamic voltage restorer (PV-DVR) with significant energy conservation. International Journal of Electric Power Energy Systems. 49: 296-307.

Hashem Nehrir M. \& Wang Caisheng. 2009 .Modeling and control of fuel cells distributed Generation applications. A John Willey \& Sons. Inc Publication.

Biyıkoglu Atilla.2005. Review of proton exchange membrane fuel cell models. International Journal of Hydrogen Energy. 30(11):1181-212.

Dursun E. \& Kilic Osman. 2012. Comparative evaluation of different power management strategies of a standalone PV/Wind/PEMFC hybrid power system. International Journal Electric Power Energy Systems. 34(1): 81-9.

C.K. Sundarabalan., K. Selvi. 2015. Compensation of voltage disturbances using PEMFC supported Dynamic Voltage Restorer. Electrical Power and Energy Systems..71: 77-92.

N. Srinivasa Rao., A. Selwin Mich Priyadharson. \& J. Praveen. 2018: Simulation of Artificial Intelligent Controller Based DVR for Power Quality Improvement. Procedia Computer Science. 47 : 153-167.

Mehrdad Tarafdar Hagh., AydaShaker., FarnazSohrabi., Irfan S.\& Gunsel. 2018. Fuzzy-based controller for DVR in the presence of DG. Procedia Computer Science. 120: 684-690.

P.Piramanathan. \& M.Ramasamy. 2013. A New Minimal Energy injection control strategy for dynamic voltage restorer using fuzzy logic controller. International Journal of Advanced Research in Electrical, Electronics and Instrumentation Engineering. 2(6).

B. Ferdi, C., Benachaiba, S., Dib, R. \& Dehini. Adaptive PI Control of Dynamic Voltage Restorer Using Fuzzy Logic. Journal of Electrical Engineering.

M. Nabipour, M., Razaz, S., GH. Seifossadat. \& S.S. Mortazavi. 2018. A novel adaptive fuzzy membership function tuning algorithm for robust control of a PV-based Dynamic Voltage Restorer (DVR). Engineering Applications of Artificial Intelligence. 53:155-175.

Bhavani, R. \& Rathina Prabha. N. 2018. Simulation of reduced rating dynamic voltage restorer using SRFANFIS controller', International Journal of Fuzzy Systems. 20(6):1808-1820. 